\title{
SOSIALISASI PHYSICAL DISTANCING UNTUK MENINGKATKAN KEWASPADAAN MASYARAKAT DALAM MENGHADAPI PANDEMI COVID-19 DI KELURAHAN ISOLA, SUKASARI, BANDUNG
}

\author{
PHYSICAL DISTANCING SOCIALIZATION TO IMPROVE \\ COMMUNITY AWARENESS IN FACING COVID-19 PANDEMIC \\ IN ISOLA VILLAGE, SUKASARI, BANDUNG
}

\author{
Suci Fika Widyana ${ }^{1)}$, Senny Handayani Suarsa ${ }^{2)}$, Asaretkha Adjane Annisawati ${ }^{3)}$ \\ ${ }_{1,2,3}$ Politeknik Pos Indonesia \\ ${ }^{1}$ Email: fika.bharata@poltekpos.ac.id
}

\begin{abstract}
Abstrak: Kasus coronavirus telah menjadi perhatian dunia dan juga tidak terkecuali Indonesia. Berdasarkan data yang dirilis oleh satgas Covid-19 di Indonesia per tanggal 15 Oktober 2020, dilaporkan jumlah kasus terkonfirmasi sebanyak hampir 350 ribu kasus. Oleh sebab itu perlu dilakukan pencegahan laju penyebaran dan memutus rantai penularan coronavirus, diantaranya melalui physical distancing. Tujuan dari kegiatan ini adalah untuk memberikan pengetahuan kepada masyarakat mengenai penyebaran coronavirus, dan memberikan pengetahuan tentang upaya pencegahan penularannya yang salah satu caranya adalah dengan melakukan physical distancing, serta pemberian sembako kepada masyarakat kecamatan Sukasari, Bandung yang terdapak Covid19. Dari pelaksanaan pengabdian masyarkat ini telah secara nyata memberikan sosialisasi mengenai physical distancing dan pemberian sembako kepada masyarakat di Kelurahan Isola, Sukasari, Bandung yang kemudian langsung didistribusikan kepada masyarakat sekitar terutama masyarakat yang terdapampak Covid-19.
\end{abstract}

Kata Kunci: Covid-19, Physical distancing, Pandemi, Kelurahan isola

\begin{abstract}
Coronavirus cases have become a global concern, and Indonesia is no exception. Based on data released by the Covid-19task force in Indonesia as of October 15, 2020, the reported number of confirmed cases was nearly 350 thousand cases. Therefore, it is necessary to prevent the spread rate and break the chain of transmission of the coronavirus, including through physical distancing. The purpose of this activity is to provide knowledge to the public regarding the spread of the coronavirus and to provide experience about efforts to prevent its transmission, one of which is by carrying out physical distancing and providing basic foodstuffs to the people of Sukasari sub-district, Bandung who are affected by Covid-19. From the implementation of this community service, this has provided socialization regarding physical distancing and the provision of basic foodstuffs to the community in Isola Village, Sukasari, Bandung, which is then distributed directly to the surrounding community, especially those affected by Covid-19.
\end{abstract}

Keywords: Covid-19, Physical distancing, Pandemic, Isola village 
INTEGRITAS : Jurnal Pengabdian

Vol 5 No 1 Juli 2021

ISSN $2580-7978$ (cetak) ISSN 2615-0794 (online)

\section{PENDAHULUAN}

Penyakit Covid-19 disebabkan oleh Severe Acute Respiratory Syndrome Coronavirus 2 (SARS-CoV-2) yang merupakan jenis baru viruscorona yang menginfeksi manusia dan belum pernah diidentifikasi sebelumnya (Shi et al., 2020; Velavan \& Meyer, 2020) sehingga menjadi penyakit fatal dan telah menjadi perhatian besar keshatan masyarakat global (Rothan \& Byrareddy, 2020). Penyakit ini pertama kali terjadi di kota Wuhan, Provinsi Hubei, Tiongkok pada akhir 2019 dan telah disebut pandemic oleh World Health Organization (WHO) (He et al., 2020). WHO sendiri menyebut virus tersebut dengan Severe Acute Respiratory Syndrome Coronavirus-2 (SARS-CoV-2) dan nama penyakitnya dinamakan Coronavirus Disease 2019 (Covid-19) (Paules, Marston, \& Fauci, 2020). Sehingga pada tanggal 11 Maret 2020 WHO menetapkan Covid-19 sebagai pandemik (Baloch, Baloch, Zheng, \& Pei, 2020; Gugus Tugas Percepatan Penanganan Covid-19, 2020). Covid-19 ini sendiri sebetulnya generasi ketiga dari coronavirus dari dua virus sebelumnya yang telah teridentifikasi yaitu Middle East Respiratory Syndrome (MERS) dan Severe Acute Respiratory Syndrome (SARS).

Kasus konfirmasi Covid-19 pertama di Indonesia dilaporkan pada tanggal 2 Maret 2020 (Syafrida \& Hartati, 2020). Data terakhir per tanggal 15 Oktober 2020 dilaporkan jumlah kasus terkonfirmasi sebanyak 349.160 dengan jumlah pasien sembuh sebanyak 273.661 dan pasien meninggal sebanyak 12.268 (Covid19.go.id, 2020). Dengan terus bertambahnya kasus penyebaran virus ini di seluruh Indonesia, tentu saja berdampak pada bidang epolisosbud, pertahanan dan keamanan, serta kesejahteraan masyarakat di Indonesia (Syafrida \& Hartati, 2020). Pemerintah telah menetapkan Covid-19 sebagai salah satu penyakit yang menimbulkan Kedaruratan Kesehatan Masyarakat (KKM) dan menetapkan KKM Covid-19 di Indonesia sehingga wajib dilakukan upaya penanggulangan, dan menyatakan bahwa pandemi Covid-19 sebagai bencana nasional (Keputusan Presiden Republik Indonesia Nomor 12 Tahun 2020, 2020).

Telah banyak upaya yang dilakukan oleh pemerintah untuk mencegah laju penyebaran dan memutus rantai penularan coronavirus ini, diantaranya melalui peraturan dan kebijakan, seperti pembuatan Undang-undang, Perpu, Kepres, 
INTEGRITAS : Jurnal Pengabdian

Vol 5 No 1 Juli 2021

ISSN $2580-7978$ (cetak) ISSN $2615-0794$ (online)

Peraturan Pemerintah, Permenkes, Surat Edaran, Maklumat dan sosialisasisosialisasi lainnya dalam bentuk benner maupun flyer. Disamping itu, upaya untuk penanggulangan infeksi Covid-19 melalui pemberian vaksinasipun masih terus dilakukan penelitian dan pengembangan (Zendrato, 2020).

Salah satu cara nyata untuk dapat menekan laju penyebaran dan memutus rantai penularan coronavirus adalah melalui physical distancing (menjaga jarak secara fisik). Menurut (Gugus Tugas Percepatan Penanganan Covid-19, 2020) physical distancing merupaka salah satu upaya pencegahan coronavirus di level masyarakat dengan tidak berdekatan atau berkumpul di keramaian atau tempattempat umum, tidak menyelenggarakan kegiatan atau pertemuan yang melibatkan banyak peserta, menjaga jarak dengan orang lain minimal satu meter, menghindari berpergian ke tempat-tempat wisata, dan menerapkan work from home (WFH). Langkah ini memerlukan peran serta dari semua komponen baik individu, pemerintah maupun masyarakat. Oleh sebab itu, masyarakat perlu diberikan informasi yang memadai mengenai bahaya dan upaya pencegahan yang dapat dilakukan oleh individu dan masyarakat (Rizky A et al., 2020). Atas dasar hal tersebut maka perlu dilakukan sosialisasi tentang physical distancing untuk meningkatkan kewaspadaan masyarakat dalam menghadapi pandemi Covid-19, salah satunya dilakukan di Kecamatan Sukasari Bandung yang merupakan daerah binaan Politeknik Pos Indonesia. Sosialisasi ini bertujuan agar masyarakat memahami secara benar dalam menyikapi virus corona.

Tujuan dari kegiatan ini adalah untuk memberikan pengetahuan kepada masyarakat mengenai penyebaran virus Covid-19, dan memberikan pengetahuan tentang upaya pencegahan penularannya yang salah satu caranya adalah dengan melakukan physical distancing, serta pemberian sembako kepada masyarakat kecamatan Sukasari, Bandung yang terdapak Covid-19.

\section{METODE}

Target sasaran kegiatan pengabdian masyarakat ini adalah masyarakat Kelurahan Isola, Sukasari, Bandung. Pelaksanaan kegiatan pengabdian masyarakat ini dilakukan melalui: pertama, kegiatan sosialisasi dan diskusi untuk memberi pengetahuan dan meningkatkan pemahaman masyarakat khususnya di Kelurahan Isola, Sukasari, Bandung tentang pentingnya menjaga jarak, menjaga 
kebersihan diri agar terhindar dari virus Covid-19. Sosialisasi disampaikan menggunakan teknik ceramah agar mudah dipahami oleh masyarakat dengan bantuan video, gambar tentang materi tersebut untuk mempermudah masyarakat menerima informasi dan meningkatkan pemahaman. Metode atau teknik ini dipilih karena disesuaikan dengan keadaan di Kelurahan Isola. Dalam penyampaian materi, masyarakat diberi bantuan media berupa modul dan flyer.

Kedua, melalui kegiatan pendampingan dan monitoring yang dilakukan selama pelaksanaan kegiatan untuk melihat kemampuan masyarakat dalam mempraktekan apa yang telah disampaikan dalam kegiatan kesehariannya. Sehingga diharapkan jika ada masyarakat yang telah terampil dapat menyebarluaskan pengetahuan dan keterampilannya tersebut kepada masyarakat lain yang ada di lingkungannya.

\section{HASIL DAN PEMBAHASAN}

Kelurahan Isola merupakan salah satu Kelurahan yang berada pada Kecamatan Sukasari Kota Bandung Jawa Barat. Kecamatan Sukasari memiliki empat Kelurahan, yakni Kelurahan Isola, Kelurahan Gegerkalong, Kelurahan Sukarasa, dan Kelurahan Sarijadi (Peraturan Daerah Provinsi Jawa Barat Nomor 2 Tahun 2016, 2016). Kegiatan pengabdian pada masyarakat ini dilakukan di Kelurahan Isola Kecamatan Sukasari. Batas wilayah Kelurahan Isola sebelah utara berbatasan dengan Desa Gudangkahuripan (Kecamatan Lembang), sebelah barat berbatasan dengan Desa Cihideung dan Desa Ciwaruga (Kecamatan Parongpong), sebelah selatan berbatasan dengan Kelurahan Gegerkalong, sedangkan sebelah timur berbatasan dengan Kelurahan Ledeng. Kelurahan Isola terdiri atas 6 Rukun Warga (RW) dan 29 Rukun Tetangga (RT). Secara geografis letak Kelurahan Isola berada pada 6 ${ }^{\circ} 50^{\prime} 10,896^{\prime \prime}$ LS - $6^{\circ} 51^{\prime} 53,64^{\prime \prime}$ LS dan $107^{\circ} 34^{\prime} 53,94$ ” BT $107^{\circ} 36^{\prime} 1,728^{\prime \prime}$ BT. Kelurahan Isola termasuk ke dalam Kawasan Bandung Utara dengan luas wilayah sebesar 179,677 hektar (Badan Pusat Statistik Kota Bandung, 2016). Untuk lebih jelasnya berikut ini dapat dilihat peta Kelurahan Isola dalam Gambar 1. 


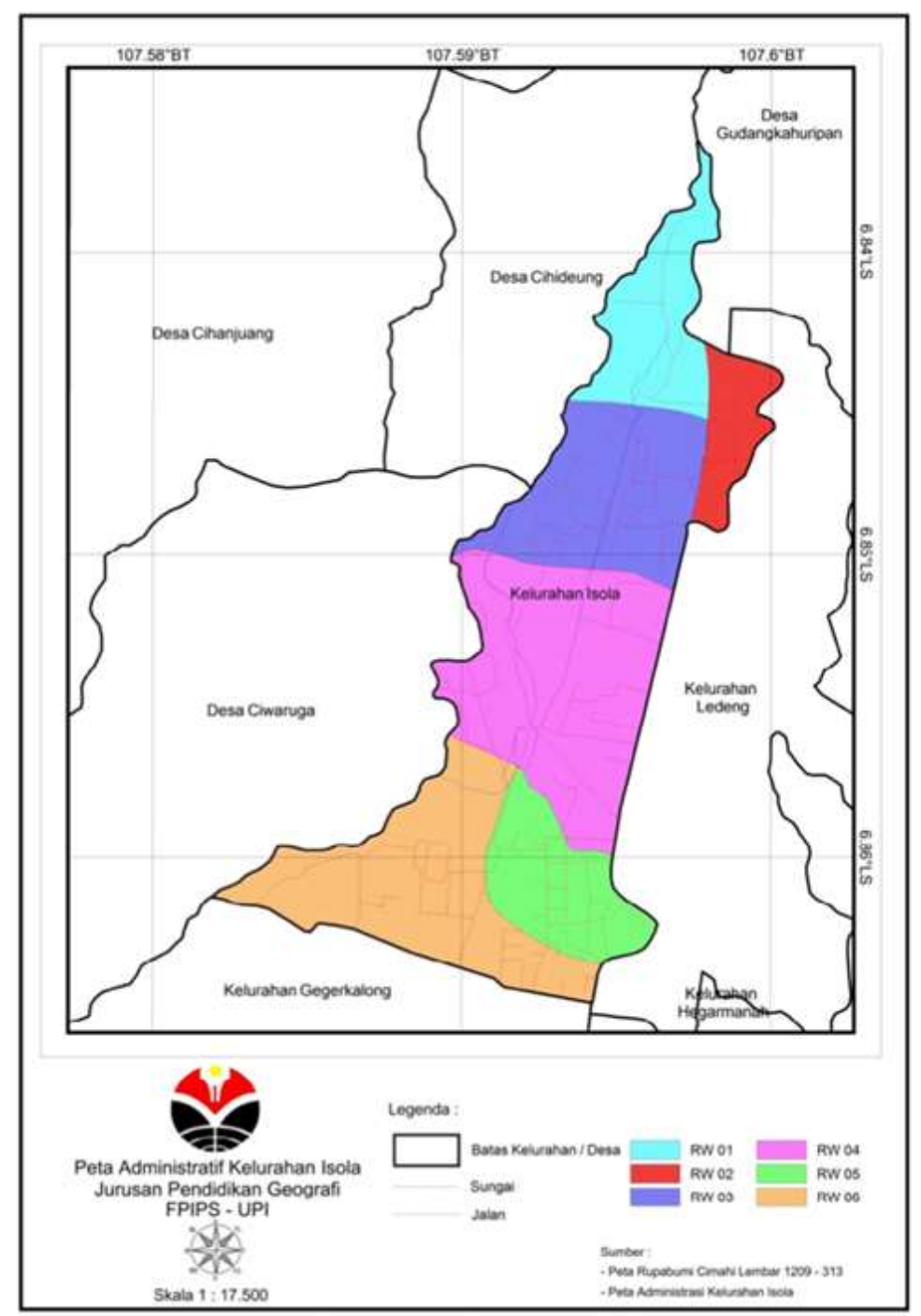

Sumber: (Urfan, Mayani, \& Yani, 2013)

Gambar 1. Peta Kelurahan Isola, Sukasari, Bandung

Berdasarkan hasil wawancara dengan sekretaris kelurahan Isola, bapak Ahmad Nurhasan jumlah Penduduk Kelurahan Isola adalah sebanyak 15.169 Jiwa dengan 3.931 Kepala Keluarga, 258 Jiwa (100 KK) masuk dalam kategori keluarga/lansia tidak mampu. Mata pencaharian warga kelurahan Isola dapat dilihat dalam Gambar 2. Berdasarkan data tersebut dapat dilihat bahwa banyak keluarga masuk dalam katergori tidak mampu, dan $41 \%$ warga memiliki pekerjaan dalam kategori lain-lain. Mereka merupakan warga yang terdampak pandemik Covid-19. 


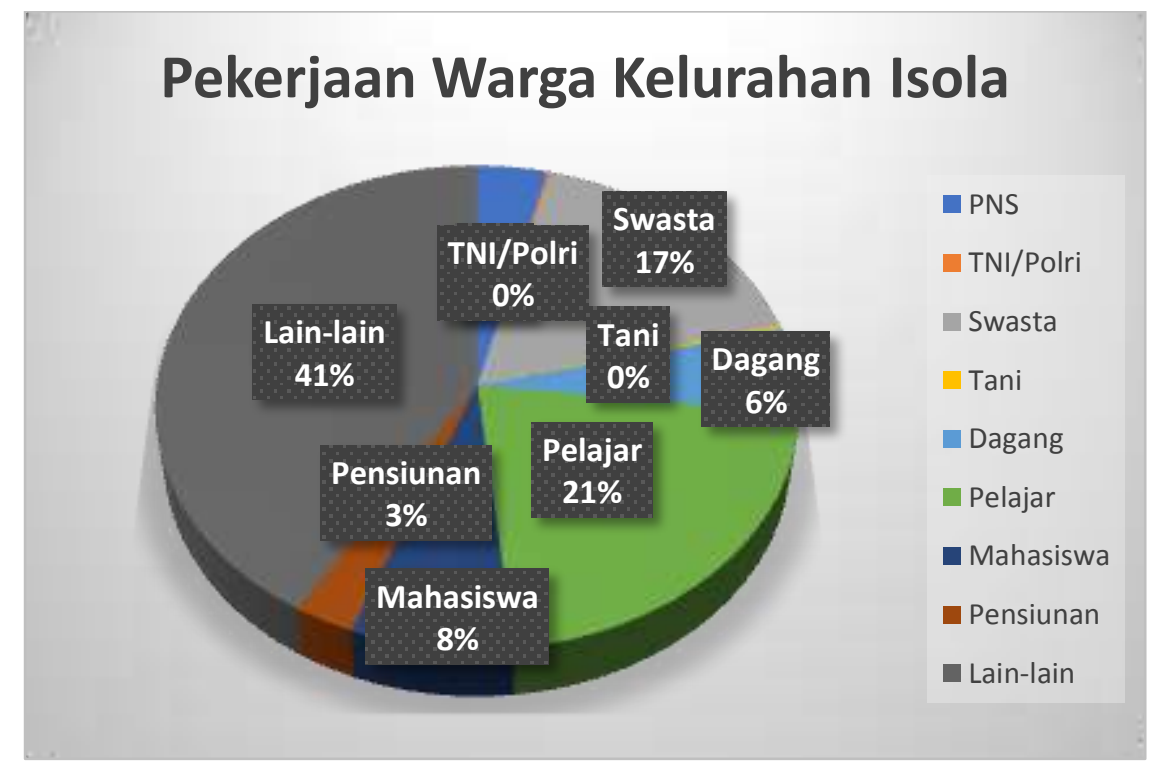

Sumber: (Badan Pusat Statistik Kota Bandung, 2018)

Gambar 2. Data pekerjaan warga Kelurahan Isola

Kegiatan sosialisasi pencegahan virus Corona atau penyakit Covid-19 dilakukan sebelum diberlakukan kewajiban penggunaan masker oleh pemerintah dan diterapkannya Pembatasan Sosial Berskala Besar (PSBB) di Jawa Barat, khususnya kota Bandung. Kegiatan dilaksanakan pada hari Senin tanggal 13 April 2020 yang dilakukan oleh Tim Pengabdian kepada Masyarakat (PkM) Politeknik Pos Indonesia bekerjasama dengan Pemerintah Kelurahan Isola, Kecamatan Sukasari, Bandung. Pada gambar 3 disajikan flyer kegiatan sosialisasi penyebaran viruscorona dalam kehidupan sehari-hari.

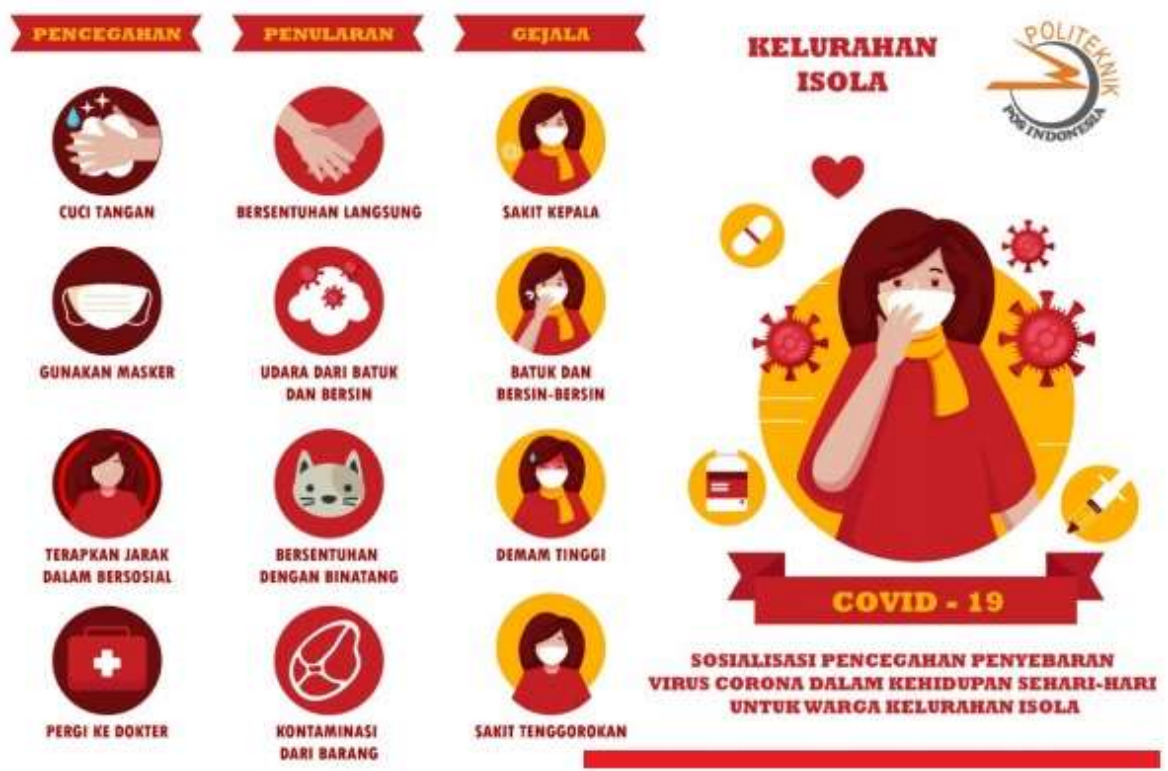

Gambar 3. Flyer kegiatan sosialisasi 
Adapun hasil kegiatan sosialisasi dapat dirinci sebagai berikut:

Tabel 1. Hasil kegiatan PkM

\begin{tabular}{|c|c|c|c|c|}
\hline No & Uraian Kegiatan & Luaran & Partisipasi Mitra & $\begin{array}{l}\text { Realisasi } \\
\text { Capaian }\end{array}$ \\
\hline 1. & $\begin{array}{l}\text { Persiapan } \\
\text { koordinasi dengan } \\
\text { sekretaris Lurah } \\
\text { kecamatan Isola }\end{array}$ & $\begin{array}{l}\text { Membuat materi } \\
\text { sosialisasi } \\
\text { physical } \\
\text { distancing. } \\
\text { Mempersiapkan } \\
\text { sembako untuk } \\
\text { dibagikan pada } \\
\text { warga terdampak } \\
\text { Covid-19 }\end{array}$ & $\begin{array}{l}\text { Mempersiapkan } \\
\text { tempat pelaksanaan } \\
\text { sosialisasi physical } \\
\text { distancing. } \\
\text { Mendata jumlah } \\
\text { warga terdampak }\end{array}$ & $100 \%$ \\
\hline 2. & $\begin{array}{l}\text { Melakukan } \\
\text { sosialisasi }\end{array}$ & $\begin{array}{l}\text { Membagikan } \\
\text { materi sosialisasi }\end{array}$ & $\begin{array}{l}\text { Membantu } \\
\text { pelaksanaan } \\
\text { sosialisasi }\end{array}$ & $100 \%$ \\
\hline 3. & \begin{tabular}{lr}
\multicolumn{2}{l}{ Memberikan } \\
sembako untuk \\
warga kelurahan \\
Isola r yang \\
terdampak Covid- \\
19
\end{tabular} & $\begin{array}{l}\text { Membagikan } \\
\text { sembako pada } \\
\text { warga kelurahan } \\
\text { Isola terdampak } \\
\text { Covid-19 }\end{array}$ & $\begin{array}{l}\text { Membantu } \\
\text { mendistribuksikan } \\
\text { sembako pada } \\
\text { warga Kelurahan } \\
\text { Isola terdampak } \\
\text { Covid-19 }\end{array}$ & $100 \%$ \\
\hline
\end{tabular}

Sumber: Penulis, 2020
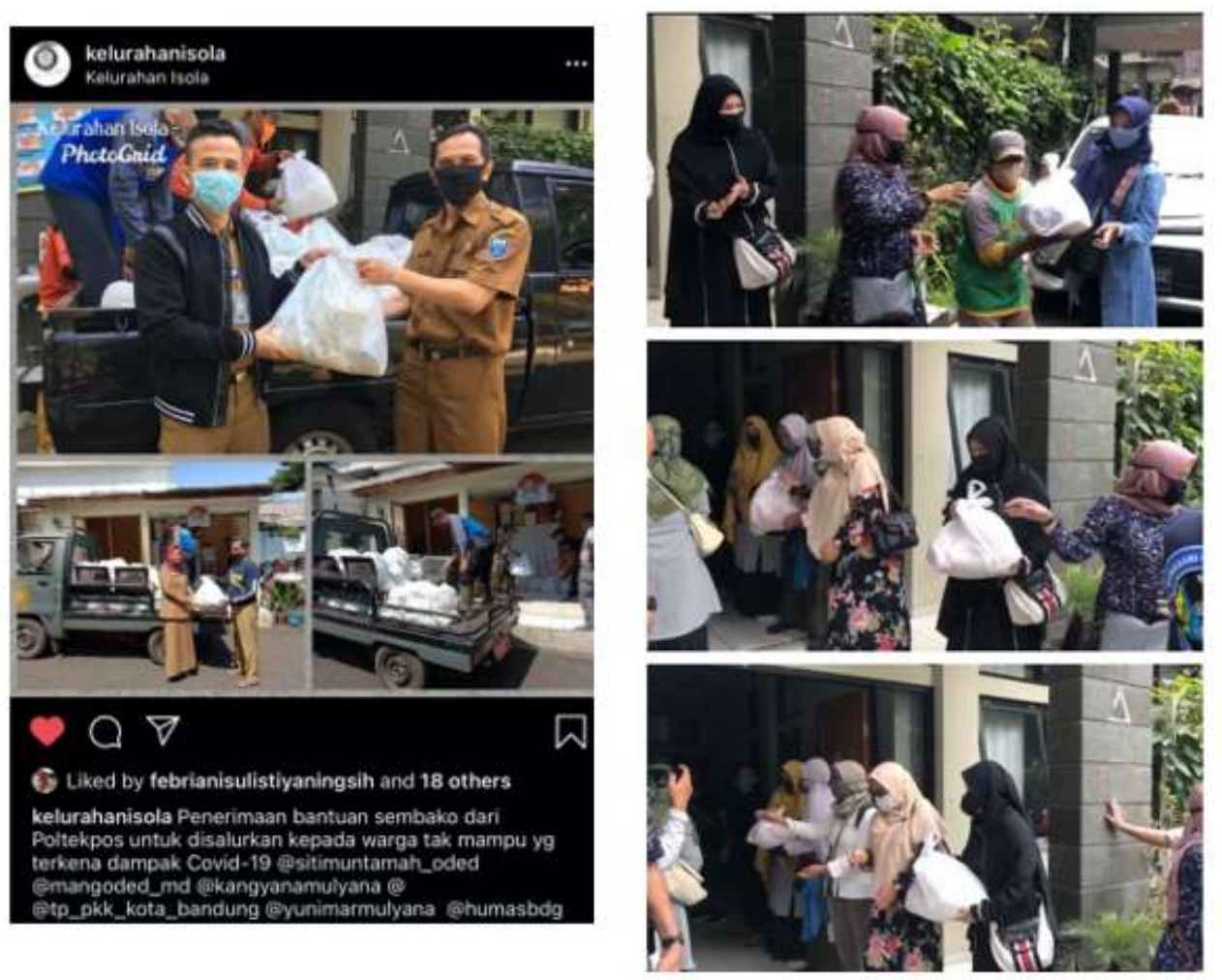

Gambar 4. Foto kegiatan sosialisasi dan pemberian sembako 
INTEGRITAS : Jurnal Pengabdian

Vol 5 No 1 Juli 2021

ISSN 2580-7978 (cetak) ISSN 2615-0794 (online)

\section{KESIMPULAN}

Dalam pelaksanaan pengabdian ini dapat disimpulkan bahwa dengan dilaksanakannya sosialisasi physical distancing telah memberikan dampak yang baik dalam meningkatkan kewaspadaan masyarakat khususnya di Kelurahan Isola, Sukasari, Bandung dalam menghadapi pandemi Covid-19. Upaya pencegahan secara individu dan masyarakat merupakan hal yang sangat penting dalam menekan jumlah kasus dan memutus rantai penularan agar kasusnya tidak semakin meningkat, salah satunya adalah dengan melakukan physical distancing disamping penggungaan masker, mencuci tangan sesering mungkin dan tentunya minum vitamin untuk memperbaiki atau menjaga sistem imun tubuh agar tetap prima.

\section{UCAPAN TERIMA KASIH}

Ucapan terima kasih disampaikan kepada Lembaga Penelitian dan Pengabdian Kepada Masyarakat (LPPM) Politeknik Pos Indonesia yang telah membarikan bantuan dana sehingga terlaksananya program ini serta tim Pengabdian kepada Masyarakat (PkM) Politeknik Pos Indonesia yang telah membantu memberikan sosialisasi Physical Distancing Covid-19 kepada masyarakat di Kecamatan Sukasari, Bandung.

\section{DAFTAR PUSTAKA}

Badan Pusat Statistik Kota Bandung. (2016). Statistik Daerah Kecamatan Sukasari 2016. Bandung: Badan Pusat Statistik.

Badan Pusat Statistik Kota Bandung. (2018). Kecamatan Sukasari Dalam Angka. Bandung: Badan Pusat Statistik.

Baloch, S., Baloch, M. A., Zheng, T., \& Pei, X. (2020). The Coronavirus Disease 2019 (Covid-19) Pandemic. Tohoku Journal of Experimental Medicine, 250(4), 271-278. https://doi.org/10.1620/tjem.250.271

covid19.go.id. (2020). Pencapaian Tinggi Kesembuhan Harian Pasien Covid-19 Sebanyak 5.810 Orang. Retrieved from https://covid19.go.id/ website: https://covid19.go.id/p/berita/pencapaian-tinggi-kesembuhan-harianpasien-Covid-19-sebanyak-5810-orang

Gugus Tugas Percepatan Penanganan Covid-19. (2020). Pedoman Penanganan Cepat Medis dan Kesehatan Masyarakat Covid-19 di Indonesia. In Gugus Tugas Percepatan Penanganan Covid-19.

He, X., Lau, E. H. Y., Wu, P., Deng, X., Wang, J., Hao, X., Leung, G. M. (2020). Temporal Dynamics in Viral Shedding and Transmissibility of Covid-19. Nature Medicine, 26(May), 672-675. https://doi.org/10.1038/s41591- 
020-0869-5

Keputusan Presiden Republik Indonesia Nomor 12 Tahun 2020. (2020). Keputusan Presiden Republik Indonesia Nomor 12 Tahun 2020 Tentang Penetapan Bencana Nonalam Penyebaran Corona Virus Disease 2019 Sebagai Bencana Nasional.

Paules, C., Marston, H. D., \& Fauci, A. S. (2020). Coronavirus Infection-More Than Just The Commont Cold. American Medical Association, 323(8), 707-708.

Peraturan Daerah Kota Bandung No 18 Tahun 2011. (2011). Peraturan Daerah Kota Bandung No 18 Tahun 2011 Tentang Rencana Tata Ruang Wilayah Kota Bandung Tahun 2011-2031 (p. 143). p. 143.

Peraturan Daerah Provinsi Jawa Barat Nomor 2 Tahun 2016. (2016). Peraturan Daerah Provinsi Jawa Barat Nomor 2 Tahun 2016 Tentang Pedoman Pengendalian Kawasan Bandung Utara Sebagai Kawasan Strategis Provinsi Jawa Barat (p. 71). p. 71.

Rizky A, S., Trisiana, A., Ajrur R, F., Algileri M, L., Syaibani, I., \& Nur F, S. (2020). Menumbuhkan Kesadaran Masyarakat Indonesia Untuk Memutus Rantai Penyebaran Wabah Covid-19. Jurnal Ilmiah Kajian Pendidikan Kewarganegaraaan, (1), 51-62.

Rothan, H. A., \& Byrareddy, S. N. (2020). The Epidemiology and Pathogenesis of Coronavirus Disease (Covid-19) Outbreak. Journal of Autoimmunity, 109. https://doi.org/10.1016/j.jaut.2020.102433

Shi, Y., Wang, G., Cai, X., Deng, J., Zheng, L., Zhu, H., ... Chen, Z. (2020). An Overview of Covid-19. Journal of Zhejiang University-SCIENCE B (Biomedicine \& Biotechnology), 21(5), 343-360.

Syafrida, \& Hartati, R. (2020). Bersama Melawan Virus Covid 19 di Indonesia. SALAM: Jurnal Sosial Dan Budaya Syar-I, 7(6), 495-508. https://doi.org/10.15408/sjsbs.v7i6.15325

Urfan, F., Mayani, E., \& Yani, A. (2013). Struktur Keruangan Peribadatan Umat Islam di Kelurahan Isola Kecamatan Sukasari Kota Bandung. Antologi Pendidikan Geografi, 1(2), 1-14.

Velavan, T. P., \& Meyer, C. G. (2020). The Covid-19 Epidemic. Tropical Medicine and International Health, 25(3), 278-280. https://doi.org/10.1111/tmi.13383

Zendrato, W. (2020). Gerakan Mencegah Daripada Mengobati Terhadap Pandemi Covid-19. Jurnal Education and Development, 8(2), 242-248. 